\title{
AN IMMANENT APPROACH TO DEATH: THEOLOGICAL IMPLICATIONS OF A SECULAR VIEW
}

Author:

Cornel W. du Toit

\section{Affiliation: \\ ${ }^{1}$ Research Institute for Theology and Religion, University of South Africa, South Africa}

\section{Correspondence to:} Cornel W. du Toit

e-mail:

dtoitcw@unisa.ac.za

\section{Postal address:}

PO Box 780, Groenkloof 0027, South Africa

\section{Keywords:}

secularisation of death; hereafter; sin and death fear of death; horizontal transcendence

\section{Dates:}

Received: 16 June 2009

Accepted: 24 Aug. 2009

Published: 12 Nov. 2009

How to cite this article: Du Toit, C.W., 2009, 'An immanent approach to death: Theological implications of a secular view', HTS Teologiese Studies/Theological Studies 65(1), Art. \#296, 8 pages.

DOI: 10.4102/hts.v65i1.296

This article is available at:

http://www.hts.org.za (c) 2009. The Authors. Licensee: OpenJournals Publishing. This work is licensed under the Creative Commons Attribution License.

\section{ABSTRACT}

The thesis of this article is that contemporary people are increasingly ousting death from their consciousness and focussing instead on the complexities of life in a context of horizontal transcendence. This replaces the Pauline notion that death is the fruit of sin and will be overcome if its real cause, sin, is vanquished through the death and resurrection of Christ. The article shows how religions, the state and civil society have abused human fear of death in the course of history. It examines the way science has 'biologised' death and the impact this has on concepts such as soul, the hereafter and identity. Reflection on the hereafter tends to make light of death. The article deals with some philosophical models (especially those of Hegel and Heidegger) that incorporate the negative (non-being, death) into life (the subject). I then outline a model incorporating death into life at a horizontal transcendental level in order to make death plausible. The example cited is Sölle's work. The article concludes with a discussion of some theological implications of an immanent approach to death.

\section{INTRODUCTION}

\section{Secularisation of death and the emergence of horizontal transcendence}

We have the potential to live longer than any generation before us - with the promise of an even longer lifespan lurking just round the corner as gene technology advances (see Fukuyama 2002:15-16). Our lives are fairly predictable, with answers in place in the event of illness or accident. It used to be very different. People died young from diseases, war and famine. Death was in the midst of life, visible to all and universally feared (terror mortis). It was also a social affair involving everyone who knew the dying person. Nowadays people usually die alone. We hide our dead and the body is disposed of as quickly and as 'professionally' as possible. It is left to outsiders.

Part of the reason for the deferential treatment of death is the belief in immortality - it persists quite stubbornly, for understandable reasons: love of the deceased and grief over the loss, the inconceivability of one's own mortality. So we console ourselves with the thought that the deceased no longer has to suffer pain and misery, is in heaven/paradise or at rest/asleep. ${ }^{1}$ But one also gets the impression that not many people take this literally any more - it is a non-literal consolatory genre, addressed to the deceased's children and relatives at funerals.

Conventional phrases and rituals are, of course, still in use, but more people than earlier feel uneasy using them, because they seem shallow and worn out. The ritual formulae of the old society, which made it easier to cope with critical life-situations such as this, sound stale and insincere to many young people; new rituals reflecting the current standard of feeling and behaviour, which make it easier to cope with the current crisis in life, do not yet exist.

(Elias 1985:24)

Civilisations are judged by the way they treated their dead. Our earliest ancestors in Palaeolithic times, the Neanderthal humans (100 000 to 35000 years ago), already buried their dead (La Chapelle and La Ferrassie in France). The portentousness of death literally defines humankind's greatest cultural artefacts, for instance the pyramids. ${ }^{2}$ The greatness of the human species lies in its rebellion against its own insignificance. Death is focal in religion ('[A]ll religions originated in the cult of the dead' - Sölle 2007:61). Not surprisingly, then, the dead (spirits, ghosts) in early cultures assumed the same traits as transcendent (divine) forces; ${ }^{3}$ the dead can favour or harm me, as witnessed in the fear and veneration of ancestors ${ }^{4}$. In many cultures people speak to the dead and take gifts to the grave (prayers and offerings). Just as there are sacred places where the deity manifests itself ( $c f$. Delphi, the Old Testament Beth-el), so there are special (holy?) places where the spirits of the dead are 'sure' to be found.

Societies have always been determined indirectly by an (often unspoken) view of death. Death is immortalised in art and is the driving force behind present-day medical research. Freud singled

1. The Reformers' rejection of the Catholic idea of purgatory meant that the source of energy associated with fear and hope had to be rechannelled. It was achieved by putting the accent on the inner life of devout people and their commitment to God (Taylor 2007:70-72). That energy has to be re-channelled in secular modernity, where rationality has supplanted the mystery and fear of transcendent metaphysical powers.

2.For the meaning of death in ancient Egypt, see Hegel (1956:216-219).

3.Cupitt (1997:86) refers to the way in which Kierkegaard has given the dead the attributes of God. He continues: 'The omnipresence of the dead is exactly like that of God in that although we take the thought of them along with us wherever we go, we also need a place where there is a special marker of their absent presence, or present absence. The marker - gravestone, altar, or whatever - makes us talk, and thereby acts as midwife of truth' (Cupitt 1997:87).

4.The experience of death in some African cultures and ancestor veneration offers interesting examples of the bond between the transcendent and the dead. The emotional restraint typical of Western death rituals is absent. The dead occupy a far more prominent place: they do not go to heaven but join the body of ancestors, who have a major impact on the fortunes of the living. One can therefore not afford to neglect them. This is evident in the large sums of money that the poorest of the poor lavish on funerals. Africans handle death far more easily than individualised secular peoplo do. It is still a communal affair; there is no concept of punishment; the dead are deather readily pictured as living on in the spirit world, stil relating to the living. They live in a shadow world (serit), but the same word, seriti, or diminish it. It does not mean that the community is entirely honest about it. That is evident in the denial of Aids sufferers by their communities. This denial is a root cause of the authorities' apparent inability to stem the Aids pandemic in Africa. 
out the death drive (thanatos), along with the sex drive (eros), as a cardinal controlling force (Marcuse 1968:149-159). It is the shadow that trails us wherever we go, relentlessly lengthening till our candle flame is snuffed. From the outset death and religion were linked, because religion is an interpretation that seeks to fit every facet of life into a coherent system of meaning.

But all that is changing. ${ }^{5}$ Commemoration of and respect for the dead, like fear of ghosts, belong to a bygone age. Death is seen as a natural part of our life cycle. This is a commonly accepted premise in the biological sciences and is increasingly apparent in popular European culture as well. In the context of what we could call horizontal transcendence the accent shifts to an inward transcendence evinced in various forms of secular spirituality. Here death is still a subject of reflection, but is not connected with transcendent entities like evil powers, judgement and a hereafter. Life itself assumes transcendent features with its openness, relational character and unpredictability.

There are various ways to interpret and cope with death and dying. What is remarkable is that death is rarely seen simply as the end of life, the way birth is seen simply as the start of life. It is usually coupled with a moral or emotional dimension like death and fear, death and judgement, death and punishment, death and sin, death and guilt, death and reward. This contrasts with the absence of any such association in a naturalist approach, where death is no more than the end of life. But the very concepts that are linked with death give those in power a lever to manipulate people - their faith, behaviour, services, obedience, subservience and the like.

Many of the metaphors used for death are also taken literally and the concept of death is often replaced by metonymies. Death is sleep, a journey to a place of rest, paradise, our heavenly home, purgatory, hell. It is linked with reward or punishment, eternal life or eternal judgement. This view has come in for increasing and valid criticism of late. But it remains the way most churches deal with death.

An alternative is to regard death as a natural part of human life. The sciences do so objectively or view it existentially as part of the human condition. Nowadays there is also a narrow secular perspective that simply ignores death and those that 'draw it into life' via secular spirituality.

The thesis of this article is that as a symbol of the human predicament, death (as the consequence of sin) is making way for a focus on the complexities of life in a context of horizontal transcendence. Dispensing with the causal connection between sin, death and salvation has caused a shift in the Reformed paradigm that calls for a rethinking of that connection.

\section{Examples of abuses of human fear of death}

\section{The church's interpretive monopoly}

The shift of attention from death to life did not happen overnight. It has a long prehistory. The Greeks, notably Epicurus, did not consciously link death with fear. He encouraged his pupils to accustom themselves to the idea that 'death is nothing to us' (Feldman 2004:102). He allayed the fear of death, saying that when thinking about one's own death, one should do so with equanimity (see Feldman 2004:102). But there are plenty of examples where both church and state abused people's superstition and fear of death.

The religions were not acquainted with Epicurus's approach. Over the ages, especially after the advent of Christianity, they

5.With reference to Mankell, Sölle (2007:14) speaks of a 'strange European revolution in the mid-50s that removed old age from our life experience and deleted death from our agond from our agenda. ... Instead youth, energy, health are the dominant theme. Cupit (1997:103) verbalises this sentime we know any we know anything, that there isn't literally any supernatural order, and there is no literally any life after death. This is all there is, and, as everyone knows, when you're dead, you're dead'. acquired a monopoly of reflection on death. After all, the religious brokers had to look after your interests when you die. The church was involved in people's dying moments and the last rites accompanying deathbed ministrations and burial. The church had a monopoly of interpreting and reflecting on death on behalf of ordinary mortals.

We all know how the church abused popular ignorance and inculcated fear of death to get people to commit themselves to its religion and lifestyle. The Middle Ages were the heyday of ecclesiastic tyranny. Elias puts it as follows:

One also has to consider why in almost all traditional statesocieties, next to the warriors represented by princes as their commander-in-chief, priests formed the most powerful and high ranking group. Priests were the traditional guardians of a society's fund of knowledge. They provided what human beings, together with some other basic requirements such as physical security and food, needed most-additional means of orientation.

(Elias 2005:210)

The basic orientation was therefore built on basic needs

In former ages human beings were exposed even more helplessly than they are today to the vagaries of nature, the accidents of illnesses, and physical insecurity, and numerous other misfortunes. They died at a much earlier age. Priests "knew" why all that happened to people. They knew how to communicate with the unseen powers and ward off their ill-will, securing their blessing through ritual, prayer, and sacrifice.

(Elias 2005:210; see also Moltmann 1996:94)

Medieval people lived in the midst of death every day. It was part of the community, as it was among the Greeks, from whom Latin Christianity grew. That soon changed under ecclesiastic influence. 'The notion of a common [my italics CWdT] judgement, englobing everyone, at the end of time was a central part of Christian belief from the earliest ages' (Taylor 2007:67). Gradually it changed from communal judgement to personal judgement - a development that was to help establish the notions of individuality and personal fate as opposed to a common destiny. In keeping with my thesis that the perception of death as a symbol of the human predicament is linked to a perception of sin as the cause of it, that perception, like death, had to be individualised. That is exactly what happened. Taylor, with reference to Bossy writes:

Bossy speaks of an early emphasis on sins of aversion, sins against charity and solidarity, which gradually makes place for an increasing concern with sins of concupiscence, sins against chastity, seen as pollution, and negation of personal holiness.

(Taylor 2007:69)

This shift towards an individualistic view of sin and death (judgement) should not be understood as a shift away from sin and death as metaphysical powers towards an immanent, individual perspective. As we shall see, that only happened in our time. In a secular society, reflection on death is no longer possible, because death hardly features in ordinary life. Whereas medieval people were overwhelmed by constant fear of death, in our time it has vanished from public consciousness (see Taylor 2007:65).

\section{Protective monopoly of the state}

The state uses individuals' insecurity, their vulnerability, to rule. It allays our fear of death (unnatural, violent death) in return for loyalty and civil obedience. The earliest states to be established played on the role of death in people's consciousness. The irony is that the biological drive for self-preservation and the daily threat of death brought people to accept a social contract in which they traded their loyalty and obedience with the sovereign for protection of their lives. In so doing, the sovereign came to dispose over life and death. Fear of death and the drives of self-defence and self-preservation are among the most powerful drives of all living creatures. ${ }^{6}$ Hobbes $(1978: 188)$ sees

6.In his Eros en cultuur (1968), Marcuse shows how by suppressing eros the state 
the 'use' of the fear of death as instrumental for government strategy: 'The Passions that incline men to Peace, are Feare [sic] of Death', and only the sovereign, with whom individuals form a social contract, can protect them against untimely death. Only the sovereign who holds human lives in his hands can exercise authority and prevent them from making constant war on each other. Hence power and fear are interdependent. Without fear those in power cannot rule. Fear of those in power (tyrants) keeps them in power.

Governments, social contracts, etc. have to do with human vulnerability and the human quest for security. We vacillate between nature and culture, between our biology and our sociology. To governments human biological vulnerability to the constant threat of death is advantageous. Today the state, to which we look to protect our lives, manufactures nuclear weapons that can wipe out life on earth. Ironically, the same state considers capital punishment inhuman and barbaric and abolishes it! The surplus power that the state arrogates means that its mandate to protect life is expanded to a mandate to dispose over life and death. The state alone has that power. That is why it used to be a crime to take your own life, for only the sovereign (and the law) has a right to dispose over life and death. Foucault (2005:81) shows how the state deals with its disposal over life and death today: 'The old power of death that symbolized sovereign power was now carefully supplanted by the administration of bodies and the calculated management of life .... ' ' This bio-power was without question an indispensable element in the development of capitalism; the latter would not have been possible without the controlled insertion of bodies into the machinery of production and the adjustment of the phenomena of population and economic processes.' The 18th century saw the development of the first state instruments as institutions of power that would keep production relations in place,

the rudiments of anatomo- and bio-politics, created in the eighteenth century as techniques of power present at every level of the social body and utilized by very diverse institutions (the family and the army, schools and the police, individual medicine and the administration of collective bodies).

(Foucault 2005:81)

Today the fear of death (at enemy hands) has largely been replaced by fear of an economic downturn or decline. Once again government is instrumental in using the fear that an economic slump will lead to unemployment and poverty to justify its style of government.

With reference to human egotistical impulses, Niebuhr (1960:41) calls self-consciousness a product of reason. People become aware of themselves when they view themselves in relation to other life and their environment. Self-consciousness strengthens the drive to preserve and lengthen life. In an ethological vein he cites animals that are instinctually confined to moderation and merely satisfy their needs. This is not the human way. 'In man the impulses of self-preservation are transmuted very easily into desires for aggrandisement' (Niebuhr 1960:41).

He continues:

Self-consciousness means the recognition of finiteness within infinity. The mind recognises the ego as an insignificant point amidst the immensities of the world. In all vital self-consciousness there is a note of protest against this finiteness. It may express itself in religion by the desire to be absorbed in infinitude. On the secular level it expresses itself in man's effort to universalise himself and give his life significance beyond himself.

(Niebuhr 1960:42)

(footnote 6 continues...)

intensifies thanatos (death drive), which then vents itself in the form of achievement to the benefit of the state (see e.g. pages 91-92)

7.It confirms my thesis that death as the cardinal problem, and hence control mechanism, is being replaced with the problem of life and, as Foucault indicates, the mechanism, is being replaced with the problem of life and, as Foucault indicates, the
manipulation of human corporeality and sexuality in such institutions as education, manipulation of hum
prisons and health.
He considers this to be the root of all imperialism. 'Thus nature's harmless and justifiable strategies for preserving life are transmuted in the human spirit into imperial purposes and policies' (Niebuhr 1960:42).

\section{Pragmatic incorporation of death into civil culture ${ }^{8}$}

The Christian atonement model links death (Christ's) with reconciliation. Without death (Christ's) there can be no reconciliation. At a horizontally immanent level that model is refined in the work of Girard (1987). Space does not permit me to explain his entire model of mimetic desire and victimisation of the scapegoat. I confine myself to the role of death in it. According to Girard, the victim's death eventually restores harmony by elevating society and religion to the plane of the sacred. Hence the Christian faith and God remain violent, because they are associated with sacrifice. Girard (1987:412) adapts Freud's thinking to suit his own. The Freudian approach fits neatly into Girard's system. Freud accentuates the reconciliatory aspect of death:

[I]t becomes clear that the reconciliatory aspect of mourning, the mourning that rejuvenates and invigorates all cultural activity, is in fact the essence of human culture... The proof that human beings identify all death with the reconciliatory victim and that the power of the sacred is called the cult of the dead, unlike the naturalistic concept of death, appears to underlie all other forms of religion.

(Girard 1987:80-81)

The death of all is linked with the death of the substitutive victim, hence death brings reconciliation and the community's future is possible because of the peace that follows his/her death. Consider, for example, the notion that all the soldiers killed in a war are the sacrifice that had to be brought to secure peace. They are venerated (elevated to sainthood), for we owe the continuation of life to them.

There is no culture without a tomb and no tomb without a culture; in the end the tomb is the first and only cultural symbol. The above-ground tomb does not have to be invented. It is the pile of stones in which the victim of unanimous stoning is buried. It is the first pyramid.

(Girard 1987:83)

Therefore, at a horizontally immanent level, death fulfils a reconciliatory function in Girard's model. Reconciliation makes the death of the victims meaningful, but it does not reflect on death per se. The accent is on the conjunctive term 'reconciliation'.

Consciousness in the sense of self-consciousness and awareness of one's unique individuality is a latecomer. As recently as the Middle Ages, individuality and the concomitant selfconsciousness did not exist, at any rate not in the same way as today. Self-awareness was inextricably linked with groupawareness. Personal ethos was group ethos and personal faith was group faith. The rise of individualism in our modern sense brought a change in self-consciousness as well. It does not mean that the group and group pressure no longer matter, but their influence is tempered by our mental autonomy and personal critical framework - something foreign to medieval individuals. The present attitude towards death should be viewed in this light.

\section{Science and the naturalness of death}

We see death altogether differently from earlier generations. It is considered a natural part of life. Without death and the succession of generations there would be no evolution and no ongoing

8.Space constraints prevent a discussion of the work of Berger (1969:61-65), who shows how the norm (nomos) of society is imprinted on human consciousness. Societal order makes death meaningful in that the individual's identification with Societal order makes death meaningful in that the individual's identification with its nomoi moart of the individual's identity) will survive after his death; or personal death is part of natural cycles; or death is abolished in self-transcending mysticism. He considers the inculcation of false consciousness omization precisely because it has also been a powerful, probably the most powerful, agency of alienation ... religion has been a very important form of false consciousness' (Berger 1969:87). 
adaptation to changing natural and cultural environments. In a scientific context the literal creation stories, the fall and the concept of a hereafter make no sense at all. From a biological point of view pain cannot be eliminated: We need it to warn us that all is not well with our bodies. Natural disasters are not sent by divine powers but are a natural part of the earth's evolution.

Biologically body and mind are one. In that framework the idea of a disembodied soul existing forever without a body is inconceivable. Human thought is an epiphenomenon of physiologically explicable brain functions. Consciousness and thought are products of human biology (electrochemical processes). The slightest disorder of our blood chemistry affects our emotions - 'the subject of my conscious experiences would seem to be very much at the mercy of my physico-chemical constitution' (Badham 1996:524). Although our mental world depends directly on brain operations and the human mind on physical corporeality, we feel that thought and mind are 'more' than just physicality and we object to scientific reductionism. The impact of my personhood can survive in my descendants (who moreover physically perpetuate a selection of my genes), in cultural artefacts that I leave behind, in the world of memory. But to our knowledge there is no way that a person can live on after death.

The advent of personal computers offered some scholars a model to rationally explain the notion of a soul and a hereafter. The hardware-software metaphor was transposed to the bodysoul relationship. It has been suggested that, given sufficiently powerful computers, we could put our memory on disk and live on in a virtual heaven without the encumbrance of our bodies. These modern Gnostics apparently fail to realise that mind without body and emotion (which I doubt if we will ever be able to programme, because it is bound up with sense perception) would no longer be mind. ${ }^{9}$

\section{Facing up to death and the impossibility of visualising death}

Death is a problem for the living. Only humans can 'think' their own death. But death itself is not thinkable. Only human beings can die their own death, that is go to meet their end and internalise it. We wonder how we will die. Some of us vividly picture a life after death and some long for the end. But actually nobody can think what it is like to be dead, for to think death is to think life. Consciousness cannot think non-consciousness. There is a difference between courage to face up to your own death and conceiving of death qua death. We can think about dying, but death itself is as unknowable as the Ding an Sich. To think death is like thinking what it is to be a stone. Even trying to think of death as nothingness is still thought. We can only conceive of death as existence in a different form or in a different place - be it Olympus, Valhalla, heaven or the world of the ancestors. We imagine ourselves being conscious somewhere else. Even imagining ourselves lying in a grave or embalmed or remaining as grains of sand, our thought about ourselves is still in the mode of conscious reflection. It is like the prince who was changed into a toad - he did not become the toad, he remained a prince in the body or form of a toad. The prince's thoughts and identity simply continued in a different form. Whatever we think - whether in archaic or modern images - the point is that we are 'thinking' death, which is actually unthinkable. Hence the imagery.

Animals are aware of their environment, but humans surpass them by being conscious of themselves. Not only are we conscious of ourselves, we are also conscious of being conscious. Our very self-consciousness is objectified and critically analysed.

9.By way of background to this notion, the Matrix films are a mandatory source. Here everyday life is enacted in a cyber world, in which humans are kept alive as mindless

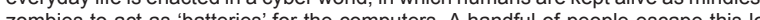
zon have to enter the cyber world to rescue humanity. But in the nend weape the quevion the question whether they, too, are not just a computer program. (See Cobb 200 a discussion of the Matrix film-series that deals with the question of reality).
In recent decades scientific study in the fields of neurology and the cognitive and brain sciences has shed light on consciousness as a brain function. No doubt we are just scratching the surface, despite greater insight and measurement of brain activities. The factors governing consciousness and self-consciousness are simply too manifold and complex to allow paradigmatic inferences. The phenomenon of consciousness depends on the electrochemical physicality of brain processes. The non-physical quality of thought and consciousness cannot exist in its own right and has to be explained as an epiphenomenon, in which experience, memory, emotion, language, intentionality, and so on converge to form consciousness. Yet they do not prescribe to consciousness. Consciousness is the creative part (the game), while the underlying physicality is comparable to the rules of the game. And just as the game is determined by the way the ball lands, so consciousness is determined by highly contingent, sensorily mediated factors.

More particularly, consciousness is not a matter of exclusively rational logic, even when we engage in manifestly empirical thought. Every mental act is emotionally mediated. All thought is co-determined by our emotions. ${ }^{10}$

\section{Death in a secular immanent context: Consumer- governed consciousness An immanent interpretation of death}

Park (2008) cites Pope Benedict XVI, who asks in his second encyclical: 'Do we really want this - to live eternally?' He continues as follows:

'Perhaps many people reject faith today simply because they do not find the prospect of eternal life attractive. What they desire is not eternal life at all, but this present life, to which faith in eternal life seems something of an impediment. To continue living forever - endlessly - appears more like a curse than a gift. Death admittedly, one would wish to postpone for as long as possible. But to live always, without end - this, all things considered, can only be monotonous and ultimately unbearable'.

(Park 2008:102-103)

Theology has always been confused when it came to thought about the soul and death. Dingemans (2000:593) refers to the humming and hawing of the Christian tradition when it comes to death. The only way to deal with the subject appears to be metaphorical, as is already evident in Paul's metaphor of the wheat kernel: What is sown is perishable, what is raised is imperishable. Dingeman (2000:595) acknowledges that to many people the idea of death is not frightening. Indeed, he says, there is no room for the kind of egocentrism that makes people see themselves as so important that they have to live forever. He confines himself to the metaphor that after death people live on in God's memory - what he calls 'God's old scrapbook'.11

Maybe that is how we should see the controversies about the historicity of Jesus' resurrection. It is not all that important that he physically rose from the dead, because death is no longer viewed in the metaphysical light of transcendent, ontological evil. To many people Jesus remains as valuable as ever without insisting on a historical resurrection. If a secular culture has shifted the accent from death to life, one would expect the theologically determined centre (Mitte) of the New Testament to shift as well. ${ }^{12}$

10.For a description of how sensory input evokes appropriate human emotion via the hypothalamus, thalamus, sensory cortex and amygdalae, see Park (2008:119121).

11.Schleiermacher (1928:244) points out that neither the Old nor the New Testament compels us 'to hold that man was created immortal, or that, with alteration in his nature, the whole arrangement of the earth relatively to him was altered as well'. Footnote 2 on the same page says that 1 Corinthians 15:56 indicates that death as such existed before the advent of $\sin$.

12. Without dwelling on the issue, I merely mention Hick's well-known The metaphor of God incarnate (1993), in which he interprets the incarnation metaphorically, criticises the doctrine of the two natures, questions literal resurrection and retains criticises the doctrine of the two natures, questions literal resurrection and retains
Jesus' value as the one who came to make God real to human beings. He 
One could make a strong case for the notion that the way death has moved to the periphery is a result of individualisation that has reached a crescendo in our time. Urbanites are lonely and often have few ties with their community. The sorrow of death lies in the reciprocal parting from loved ones. If we relativise our ties with loved ones, we relativise death. Life consists in meaningful relationships and death is the absence or severance of these.

A secularised view of death envisages a subject who is no longer porous, influenced and infiltrated by all manner of superstitions and scary stories. Modern people have a buffered identity grounded in the autonomous reason of a self-critical, selfevaluating subject (see Taylor 2007:83).

If death is seen as natural and fear of punishment and eternal judgement by a terrifying God is relativised, attitudes towards mortality change. Gore Vidal's novel Messiah (1956) is still an interesting example. It tells of the emergence in modern times - in the absence of death as a transcendent threat - of a cult in the dominant religion that celebrates death as a natural event. A few quotations illustrate the point. The protagonist, Cave, in the story is an ordinary employee in a firm of undertakers. He is so used to handling dead bodies that death becomes commonplace and he loses all fear of it. He starts talking about death in a way that makes people actually long for that peace:

Death is nothing; literally nothing; and since, demonstrably, absence of things is a good; death which is no thing is good ... Death is neither hard nor bad. Only the dying hurts' (p. 66); 'We're selling the truth about life [the naturalness of death CWdTl and that's something that nobody, but nobody has ever done before' (p. 101); 'Yes, Cave life will be wonderful when men no longer fear dying. When the last superstitions are thrown out and we meet death with the same equanimity that we have met life. No longer will children's minds be twisted by evil gods whose fantastic origin is in those barbaric tribes who feared death and lightning, who feared life. That's it: life is the villain to those who preach reward in death, through grace and eternal bliss, or through dark revenge...

(Vidal 1956:101)

According to Sölle, consumer-governed consciousness in our technocratic society has ousted death and left us the poorer. Let us not kid ourselves that in consumer society time is optimised and that we do not have time to waste on death. In that society, time is not seen as something that will run out and end in death, but is fully converted into money. The meaning of life is symbolised by money and, ironically, manifested in the mountains of waste we produce. We should rather 'waste' time reflecting on our limited time and its quality in light of mortality. The consumer mentality destroyed our capacity for pathos, as well as our ability to experience suffering (Sölle 2007:14-15). '[T]he way to overcome the consumer society leads through the rediscovery of death' (Sölle 2007:47).

\section{Theological implications of an immanent approach to death \\ Death as punishment for sin}

Dingemans (2000:347-349) points out that for centuries the churches emphasised human guilt and sinfulness, along with forgiveness and reconciliation. In his view churches used this to keep people small and dependent on an institute of salvation that offered them forgiveness. But nowadays people no longer feel so guilty and sinful, so the churches have to shift their emphasis. He proposes that they put the accent on the unfathomable nature of evil. Of course, that could easily turn into a new kind of transcendent metaphysics, unless the mystery is linked with aspects of the human condition. He does, however, reject traditional causal explanations of evil.

(footnote 12 continues.

interprets the witnesses to the resurrection as analogous to Paul's Damascus experience: 'For as we trace the stream of tradition back through successive layers we find less and less of the physically miraculous and more of the spiritually transforming' (Hick 1993:25, also see 99-111).
Dingemans also rejects a causal connection between sin and death. ${ }^{13}$ He puts it as follows [my translation - CWdT]:

One can no longer say that death is the consequence of or punishment for sin - that is simplistic. One can say, however, that human ambivalence about death is the flipside of human freedom.

(Dingemans 2000:254)

He sees God's action in the world - to my mind correctly - as that of luring people with love (Dingemans 2000:586-587). Christ's second coming he regards as a metaphor.

In a similar vein, Ricoeur objects to the basic notion in sacrificial theologies of a death both offered for all people [as a result of their sinfulness - CWdT] and destined to satisfy the implacable justice of a God who demands satisfaction from them (Ricoeur 2009:71).

Hence Ricoeur rebels against this juridicizing of the whole problematic and against this sacrificial theory in which I see the worst use of faith's intelligent understanding of itself' (Ricoeur 2009:71). To him the accent is not so much on justification of sinners but on justification of existence (Ricoeur 2009:44). Jesus' kenosis should be seen as final with no prospect of resurrection - it is radical detachment (self-renunciation). Ricoeur (2009:45) cites Léon-Dufour's rejection of the emphasis on personal survival in the orientation to the eschaton: 'Jesus used language other than that concerning the after-life and the end of time, and in this he departs from the prophetic tradition, where everything is future'.

Just as the story of paradise is linked with sin, Paul links sin with death. ${ }^{14}$ That implies that the normal cycle of all life that ends in death is likewise a consequence of sin. If the dilemma of the worldview in Paul's day is condensed into fear of death that can strike at any time, and if that fear is transposed to the real cause of the dilemma (i.e. sin), it follows that the solution to $\sin$ is also the solution to death. Paul locates that solution in Jesus' death and resurrection. ${ }^{15} \mathrm{Sin}$ as the root cause of death/the human predicament, like liberation from it through the Christ events, is seen as a metaphysical entity. There is no physical connection between sin and death or between Jesus' death and absolution of sin and the elimination of death. Sin is a (metaphysical) power to which humans have been sold, a power that holds them in thrall. Naturally that power is personified by the devil, the transcendent personification of sin, death and hell. Sin affects everyone - from infants ${ }^{16}$ to prophets to devout believers: they all die, no matter what qualities they possess. In this context sin is our fate, just as death is. Sin does not indicate specific transgressions, although it includes all of them. ${ }^{17}$ By the same token reconciliation is a metaphysical matter. It is governed by powers beyond and greater than humankind.

13.A key verse in Protestant Christianity is Romans 6:23: Death is the wages of sin. According to Sölle, this refers not so much to physical death but to the death of people who cannot live, because their social circumstances keep them in captivity. Today the rule of the pax romana has made way for the pax americana. Authoritarian religion must be replaced by humanitarian religion (Sölle 2007:42). I do not find this interpretation convincing. It merely seeks to temper the radicalness of the Pauline verse.

14.Spangenberg (2009:226) indicates that nothing in the second creation story (Gn $2: 4 b-3: 24)$ suggests that Adam was created immortal, as Augustine and other the theologian would like us to believe. The link Augustine made between sexual desire and 'original sin' is also wrong, because the human beings in Genesis 2 to 3 were not asexual before they ate the fruit (Spangenberg 2009:227). Barr cited in Spangenberg 2009:234) indicated that Paul's use of the Genesis story to link all death with the so-called fall of man does not fit the actualities of the text. The narratives of the virgin birth are also not concerned with original sin but rather with Jesus' honour and status (Spangenberg 2009:239).

15. Interestingly, the history of Christianity puts the accent on the exaltation of the Easter events rather than on Jesus' life. After all, his death should be linked dialectically with what $\mathrm{He}$ had lived for, which could be summarised as recognition and exaltation of human beings irrespective of convention. For a refutation of the metaphysical foundation of the Easter events (whether in Anselm's theology or Abelard's), see Depoortere (2008:98-100).

16. Hence Augustine's peccatum imputatum / peccatum inhaerens distinction and the need for infant baptism.

17.A plausible alternative is Schleiermacher's view of sin as the experience of human insignificance (creatureliness) in the experience of a God encounter (Schleiermacher 1928:271-272, 282-285). 
Barth and Moltmann are examples of how a metaphysical ontotheology - or rather, an ontothanatology - may be regarded as a deeper dimension of the natural phenomenon of death. Barth (1960:632) and Moltmann (1996:90) distinguish between death as a natural phenomenon and a religio-metaphysical phenomenon (the second/eternal death). As a metaphysical phenomenon it requires the no less metaphysical postulate of sin as the cause of death. In both instances the metaphysical cause is traced to the first Adam and the fall (Barth 1960:633, 634; Moltmann 1996:85). Barth (1960:638-639) refers to the 'natural' view of death in both the Old and the New Testament. It is not portrayed as fearful, as the second (metaphysical) death is. 'It might be asked whether dying as the natural end of human existence is not to be understood as an intrinsic evil but not a punishment [sic]. It might be pointed out that death is a relative evil, but in the last resort no more, which all available experience shows to belong to the nature of all living creatures. These considerations are all true, but they are only secondary' (Barth 1960:631). The primary image is the fearful second death, especially as described in the Apocalypse ... ' [I]t is God Himself who encounters him [humans - CWdT] as his enemy ... Death in this sense is clearly unnatural [read metaphysical - CWdT]. It is, so to speak, the death in death' (Barth 1960:633-634, 626). Faith in Christ's atoning sacrifice removes fear of the second death, so the first (natural) death is seen as sleep - without dread (Barth 1960:634). It is the postulate of what I call an ontothanatology, with all the concomitant metaphysical baggage, that gives rise to all the other enigmas that characterise Reformed theology, such as the metaphysical view of the fall; the connection of the fall with death and the 'second death'; the dependence of the meaning of the Easter events on this postulate; and the need for the doctrines of predestination and election, with all the religious, cultural and political hegemony and chauvinism to which it gave rise in the West.

The way Barth and Moltmann (as examples) present immortality forms part of this same ontotheological interpretation. 'Man as such, therefore, has no beyond. Nor does he need one, for God is his beyond' (Barth 1960:632); 'God's indwelling eternity gives to created beings eternal time. God's indwelling presence gives to created beings for ever the "broad space in which there is no more cramping"' (Moltmann 1996:308). The question is once again whether we understand what we are talking about, since all these ideas are assimilated into the realm of the Totally Other about which we can say nothing.

If the causal link between sin and death is replaced by that between life and death, and the dualism of body and soul with the notion of a human being as a holistic whole, the New Testament worldview couched on sin-death and body-soul lines has to be adjusted. At a secular level that is already happening. Many people see death as the natural end of biological life, sin as an immanent, relational problem and meaningful living as a challenge, which religion helps us to face in a horizontally transcendent context. Horizontal transcendence is manifested in Jesus as God's incarnate face on earth that guides us to meaningful life.

\section{On soul, hereafter and identity}

It is common knowledge that the notion of the soul as an insubstantial entity that leaves the human body after death is a neo-Platonist idea, adopted by Augustine and adapted first by Aquinas and later by Descartes. This dualistic view has been questioned in recent times, partly as a result of a reappraisal of human corporeality and in light of the findings of cognitive and brain research. The soul represents human consciousness, identity and intentionality and these, while more than mere physicality, cannot exist or be understood without it. The concept of self has also changed, mainly through a shift from a community-based self (up to the Middle Ages) to the modern, individualised self. In the development of that modern, individualised self the accent is on the autonomy of the human individual with his or her discriminating reason. Although the concepts of soul, self and consciousness are subject to social and religious interpretation, ${ }^{18}$ their biological basis is irrefutable. Dawkins's question about when the soul was 'injected' into humans remains valid for those who espouse a traditional view. Dawkins writes:

In plain language, there came a moment in the evolution of hominids when God intervened and injected a human soul into a previously animal lineage. (When? A million years ago? Two million years ago? Between Homo erectus and Homo sapiens? Between 'archaic' Homo sapiens and H. sapiens sapiens?).

(Dawkins 1996:561)

Closely related to the idea of the human soul is the question of identity. Like the human mind, the human body is forever changing. Human identity is dynamically mutable. Every phase in human development is significant in its own right and influences our sense of identity. We cannot divorce our identity from our unique personal experience and development. Cloned identity is not identity at all, for it does not share the person's experiential history. If there were two or three exact replicas of me, they would still not be me. The same applies to the human soul. If I were to have a different (glorified) body hereafter or simply live on as 'soul', it would be in the form of memory (the software metaphor). But given embodied consciousness we cannot conceive of it without physicality. Alter human biology and the human person changes. (See Badham 1996:523; for identity, see Hick 1996:529-538).

\section{Immanent incorporation of death into life: Death in a context of secular spirituality Heidegger and my death as a way of revealing Being (Sein)}

To think of death in such terms as sin, punishment, judgement and reward is to distract attention from its radicalness. It is what Heidegger would call mindless escapism (das Man - roughly equivalent to 'John Soap'). Every attempt to circumvent death - be it by way of metaphors, Romanticism, beliefs in paradise or images of eternal life - falls in this category. But why do we have to be compelled to face up to death in all its radical finality? The only justification would be if such an approach to death is indispensable for authentic living.

The catastrophes of World War II made reflection on death a crucial concern, evident in post-war existentialism. But how legitimate is reflection on death and who decides on its legitimacy? Heidegger wrote about death in that climate of crisis. The very commonplaceness of death during a war exacerbates the risk of escapism and inauthentic living. Reflection on death becomes banal, reduces it to the sure knowledge that we will all die one day. ${ }^{19}$ People die every day; it is a familiar event in the world around us. Dying (except when I myself die 'one day') is whittled down to an attitude of 'you can prevent death' (by avoiding unnecessary risks, for example) (Heidegger 1976:253). Heidegger (1976:247) wants to integrate reflection on death with Dasein. The existential interpretation of death even precedes our physical existence ('Id]ie existenziale Interpretation des Todes liegt vor aller Biologie und Ontologie des Lebens'). An existential orientation to death literally: being-towards-death is grounded in caring concern ('[d]as Sein zum Tode gründet in der Sorge' Heidegger 1976:259). We go to meet death alone, leaving all human relationships behind, and that is what makes authentic existence possible. Existence becomes inauthentic (uneigentliches Sein zum Tode) when it lapses into banality. Heidegger describes death in terms of 'die eigenste, unbezügliche, gewisse, unbestimmte,

18.For the fluid nature of present-day individualism, see Teske (2000:198-203), who puts it as follows: '[B]ut to illustrate the contingency of selfhood and to suggest that there is an open-endedness to that contingency which leaves room for us, as a human community, is to reconstruct in ways that enable the living of more meaningful, man comith points away from a view of persons as having essences, or of having "souls".

19.'Die Explikation des alltäglichen Seins zum Tode hielt sich an das Gerede des Man man stierbt auch einmal, aber vorläufig noch nicht' (Heidegger 1976:255). 
unüberholbare Möglichkeit des Daseins' (the personal, certain, indeterminate [non-relational], unrepeatable possibility of Dasein). Death is not something we preside over, but an existential possibility ('Seinsmöglichkeit des Daseins' - Heidegger 1976:261). The possibility pertains to authentic Dasein, existential fulfilment. Death as a possibility is the absolute impossibility of Dasein ('die Möglichkeit der Unmöglichkeit' - Heidegger 1976:262). Die unbestimmtheit, non-relational nature of death makes it an inexorable lot from which no-one can save us (Heidegger 1976:263). Authentic Dasein requires us to face up to the solitariness of our own death and assimilate it. Such solitary acceptance prevents Dasein from lapsing into banality and enables it to be authentic ${ }^{20}$ ('Diese Vereinzelung ist ene Weise des Erschliessens des "Da" für die Existenz' - Heidegger 1976:263). We find the same idea in Sölle's work when she looks death in the eye and meaningfully implicates it in life. One of Derrida's last responses to the question 'how to accept', 'to affirm life', 'how to take responsibility for your life/name' was:

... no, I never learned-to-live. In fact not at all! Learning to live should mean learning to die, learning to take into account, so as to accept, absolute mortality (that is, without salvation, resurrection, or redemption neither for oneself nor for the other).

(Derrida 2007:24, see also p. 14)

He sees life as survival 'because survival is not simply that which remains but the most intense life possible' (Derrida 2007:52).

\section{Incorporating the negative}

Merleau-Ponty (1968) made the point that the visible world parasitises phenomenologically on the invisible world. We cannot perceive what is if part of it remains invisible (we see everything from one angle only and mentally reconstruct the object in its totality). Human nature is not immutable (not fixed $a$ priori). We are constantly changing (existence precedes essence). We have imagination and a negative ability to visualise things differently from the way they are. These existential qualities are intimately linked with death and awareness of death. 'There is ... no life without the consciousness of that life, no life without death and no consciousness of life without consciousness of death' (Priest 1998:42).

Existential philosophy should be read against the background of Hegel, especially his Phenomenology of spirit (1977). I confine myself to pointing out that Hegel portrays the relationship between subject and object (Gegenuber) as a process in which the subject first has to lose herself (die) in order to regain life through the object's recognition of her. He is par excellence the philosopher who positively incorporates the generative influence of the negative. Death (the negative) is the generative power in Hegel's dialectics.

[T] his is the tremendous power of the negative; it is the energy of thought, of the pure ' $I$ '. Death, if that is what we want to call this non-actuality, is of all things the most dreadful, and to hold fast what is dead requires the greatest strength.... But the life of Spirit is not the life that shrinks from death and keeps itself untouched by devastation, but rather the life that endures it and maintains itself in it. It wins its truth only when, in utter dismemberment, it finds itself. ... Spirit is this power only by looking the negative in the face, and tarrying with it. This tarrying with the negative is the magical power that converts it into being.

(Hegel 1979:19)

These examples show that the immanent approach to death, drawing death into life, is a modern departure. It is perpetuated in postmodernity in a distinctive way, characterised by dissociating death from sin, guilt, judgement and a hereafter.

\section{CONCLUSION}

Severing the causal connection in a context of horizontal

20.'Das Vorlaufen enthüllt dem Dasein die Verlorenheit in das Man-selbst und bringt es vor die Möglickeit, auf die besorgende Fursorge primär ungestützt,es selbst zu sein, selbst aber in der leidenschaftlichen, von den Illusion des Man gelösten, zu sein, selbst aber in der leidenschaftlichen, von den Illusion des Man gelösten,
fakitschen, ihrer selbst gewissen uns sich ängstenden Fremdheit zum Tode' (Heidegger 1976:266). transcendence entails shifting the focus away from a closed (unthinkable) metaphysical transcendence to openness to life. Openness to life means facing up to one's own mortality. That is biologically rooted in our humanness, which is characterised by freedom and ongoing design.

A theology directed to the complexities of life focuses on love as a driving force, illustrating both the extreme vulnerability and the courage of human beings. Love exemplifies horizontal transcendence because it is always relationally directed outwards. Its nature is to assimilate the negative into itself. That can be applied meaningfully to the Christian model of reconciliation. In a secular context the dilemma of death is replaced by a search for meaningful living. A focus on life in all its facets can hardly degenerate into closed immanentism, considering the human condition of structured incompleteness and the transcendent, structured nature of human thought. Open immanentism or horizontal transcendence manifests in different forms of secular spirituality (see Du Toit 2006:1251-1286). Taylor writes:

What pushes us one way or the other is ... our over-all take on human life, and its cosmic and (if any) spiritual surroundings. People's stance on the issue of belief in God, or of an open versus closed understanding of the immanent frame, usually emerge out of this general sense of things.

(Taylor 2007:550)

He continues:

[W]e could try to show how deep and powerful are the meanings of ordinary life, the satisfaction of love, of work, the enjoyment of the natural world, the riches of music, literature, art. This sense of the value of ordinary living is one of the constitutive elements of modern culture.

(Taylor 2007:711)

To present day secular people it is not a matter of the existence of some transcendent realm and how to get there, but of how to live meaningfully.

In a context of horizontal transcendence death serves to define life. Sölle (2007:49) sees it as a challenge to experience life in its fullness. Secularising death implies secularising the metaphysically 'unknowable' vertical transcendence. That is evident in people's immanent grappling with those facets of life that are marked by horizontal transcendence: internalising of mortality; loving openness; a sense of unfulfilment; a search for meaningful relationships; and interaction with diversity and new experience, to name but a few. It is a spirituality that takes responsibility for what we do to one another and our planet; a spirituality of courage that does not live in denial of human nature; a spirituality of hope awaiting the openness to life that brings fulfilment.

Sölle (2007:32-33) writes: 'It is hard work to leave life behind, but it is not impossible'. The reason why we ousted death from our consciousness was mainly our fear of death. Her critique of egothanatology transposes my death to the death of someone else. With reference to Levinas and Buber she points out that someone else's death affects us more than our own. After all, while I am alive my own death is always fictional (Sölle 2007:32-33). Her theology of mutuality focuses on creation, and is a product of her liberation theology; '... I see our Mother, the earth, hanging on the cross today' (Sölle 2007:46). The turn to the earth entails a rediscovery of the rhythm of life. 'We need a new spirituality that knows and accepts the rhythm of life' (Sölle 2007:49). 'Religion's role is to remind people of limits, to give them practice with limits, to arouse consciousness of the limits of natural existence, not to deny these limits.' Religion's 'victor mentality' vanquishes death: 'It denies finitude and transitoriness instead of accepting death "as reality in myself, as a spiritual space"' (Sölle 2007:84). Life without relationships on earth is dead. Death is a metaphor for living to the full here and now, protesting against any form of inauthentic life, consumerism and technocracy; a metaphor for 
living in mutuality, directed to others; a metaphor for relational life, for radical immanentism that is open to what lies ahead.

We might ask what harm it does if people insist on a paradisial hereafter where we live forever. It should be clear from the foregoing that such a belief is not necessarily natural, but rather the residue of ingrained fears or outdated interpretive schemes. But the crucial point is that by either removing death from life secular fashion or negating it by way of a blissful hereafter we end up forfeiting the significance of death qua finality for authentic living.

\section{REFERENCES}

Arendt, H., 2005, 'On violence', in N. Scheper-Huges \& P. Bourgois (eds.), Violence in war and peace, pp. 236-243, Blackwell, Oxford.

Badham, L., 1996, 'Problems with life after death', in M. Peterson, W. Hasker, B. Reichenbach \& D. David (eds.), Philosophy of religion, 3rd edn., pp. 521-528, Oxford University Press, New York.

Barth, K., 1960, Church dogmatics: The doctrine of creation, III/2, T\&T Clark, Edinburgh.

Bennett, G., Martinez, J.H., Peters, T. \& Russell, J. (eds.), 2008, The evolution of evil, Vandenhoeck \& Ruprecht, Göttingen.

Berger, P.L., 1967, The sacred canopy, Anchor, New York.

Cobb, K., 2005, Theology and popular culture, Blackwell, Oxford.

Cupitt, D., 1997, After God: The future of religion, Weidenfeld \& Nicolson, London.

Dawkins, R., 1996. 'Science discredits religion', in M. Peterson, W. Hasker, B. Reichenbach \& D. David (eds.), Philosophy of religion, 3rd edn., pp. 559-562, Oxford University Press, New York.

Dennett, C., 2006, Breaking the spell, Allen Lane, London.

Depoortere, F., 2008, Christ in postmodern philosophy, Clark, London.

Derrida, J., 2007, Learning to live finally: The last interview, Palgrave, Bosingstoke.

Dingemans, G.D.J., 2000, De stem van de roepende, Kok, Kampen.

Du Toit, C.W., 2006, 'Secular spirituality versus secular dualism: Towards postsecular holism as a model for a natural theology', HTS Teologiese Studies/Theological Studies 62(4), 1251-1286.

Elias, N., 1985, The loneliness of the dying, Blackwell, Oxford.

Elias, N., 2005, 'Knowledge and power', in N. Stehr \& M. Volker (eds.), Society and knowledge, 2nd rev. edn., pp. 203-242, Transaction, New Brunswick.

Feldman, F., 2004, Pleasure and the good life, Clarendon, Oxford.
Foucault, M., 2005, 'Right over death and life', in N. ScheperHuges \& P. Bourgois (eds.), Violence in war and peace, pp. 78-82, Blackwell, Oxford.

Fukuyama, F., 2002, Our posthuman future: Consequences of the biotechnology revolution, Profile, London.

Girard, R., 1987, Things hidden since the foundation of the world, Athlone, London.

Hansen, I. \& Norenzayan, A., 2006, 'Between Yang and Yin and heaven and hell: Untangling the complex relationship between religion and intolerance', in P. McNamara (ed.), Where God and science meet: The psychology of religious experience, vol. 3, pp. 187-212, Praeger, London.

Hegel, G.W.F., 1956, The philosophy of history, Dover, New York.

Hegel, G.W.F., 1977, Phenomenology of spirit, Clarendon, Oxford.

Hick, J., 1996, 'Resurrection of the person', in M. Peterson, W. Hasker, B. Reichenbach \& D. David (eds.), Philosophy of religion, 3rd edn., pp. 529-538, Oxford University Press, New York.

Hick, J., 1993, The metaphor of God incarnate, SCM, London.

Hobbes, T., 1968, Leviathan, ed. C.B. MacPherson, Penguin, Harmondsworth.

Marcuse, H., 1968, Eros en cultuur, Bijleveld, Utrecht.

Merleau-Ponty, M., 1968, The visible and the invisible, Northwestern University Press, Evanston.

Moltmann, J., 1996, The coming of God: Christian eschatology, SCM, London.

Murphey, N., 2002, Religion and science: God, evolution, and the soul, Pandora Press, Kitchener.

Niebuhr, R., 1960, Moral man and immoral society, Scribner, New York.

Park, R.L., 2008, Superstition: Belief in the age of science, Princeton University Press, Princeton.

Priest, S., 1998, Merleau-Ponty, Routledge, London.

Ricoeur, P., 2009, Living up to death, University of Chicago Press, Chicago.

Schleiermacher, F., 1928, The Christian faith, T\&T Clark, Edinburgh.

Sölle, D., 2007, The mystery of death, Fortress Press, Minneapolis.

Spangenberg, I.J.J., 'The doctrines of original sin and the virgin birth: Divine revelation or human construct?', Verbum et Ecclesia 30(1), 221-242.

Taylor, C., 2007, A secular age, Belknap Press, Cambridge, Mass.

Teske, J., 2000, 'The social construction of the human spirit', in N. Gregersen, W.B. Drees \& U. Görman (eds.), The human person in science and theology, pp. 189-212, T\&T Clark, Edinburgh.

Vidal, G., 1977, Messiah, Panther, London. 